\title{
Pengaruh Motif Berprestasi dan Self Efficacy Terhadap Pencapaian Target Penjualan Distributor
}

\author{
Ayu Agustina Indra Yanti ${ }^{* 1}$, Lulup Endah Tripalupi ${ }^{2}$, Iyus Akhmad Haris ${ }^{3}$ \\ Program Studi Pendidikan Ekonomi \\ Universitas Pendidikan Ganesha \\ Singaraja, Indonesia
}

\begin{abstract}
e-mail: ayuagustina.indrayanti@gmail.com¹, tripalupilulup@gmail.com², iyus.haris55@gmail.com³
\end{abstract}

Pengutipan:

Yanti, A. A. I.,

Tripalupi, L. E.

Haris, I. A.

(2020). Pengaruh

Motif Berprestasi

dan Self Efficacy

Terhadap

Pencapaian

Target Penjualan

Distributor

Jurnal Pendidikan

Ekonomi

Undiksha, 12 (1),

78-88

\begin{abstract}
Abstrak
Riwayat Artikel Tanggal diajukan: 8 Januari 2020

Tanggal diterima 4 Juni 2020

Tanggal dipublikasikan: 29 Juni 2020

Penelitian ini memiliki tujuan untuk mengetahui pengaruh motif berprestasi dan self efficacy terhadap pencapaian target penjualan Distributor Tiens Bali secara parsial dan simultan. Rancangan penelitian menggunakan jenis penelitian kausal. Populasi yang digunakan adalah seluruh distributor yang terdaftar di Tiens Authorized Store 618 sebesar 4.169 orang. Sampel penelitian ini berjumlah 371 responden menggunakan metode proportional random sampling. Teknik pengumpulan data dilakukan dengan penyebaran kuesioner dengan skala likert diolah menggunakan teknik analisis regresi linear berganda. Hasil analisis data menunjukkan bahwa ada pengaruh positif dan signifikan secara parsial motif berprestasi terhadap pencapaian target penjualan para Distributor Tiens Bali, ditunjukkan dari nilai $t=13,491$ dengan nilai Sig. sebesar 0,000 . Self efficacy memiliki pengaruh positif dan signifikan secara parsial terhadap pencapaian target penjualan para distributor Tiens Bali, ditunjukkan dari nilai $t=12,915$ dengan nilai Sig.sebesar 0,000. Motif berprestasi dan self efficacy memiliki pengaruh positif secara simultan terhadap pencapaian target penjualan para distributor Tiens Bali, ditunjukkan dari nilai $F=323,925$ dan nilai Sig. sebesar 0,000 .
\end{abstract}

Kata kunci: motif berprestasi; self efficacy; target penjualan

\begin{abstract}
This research aims to determine the effect of achievement motives and self efficacy on the achievement of sales targets for Tiens Bali distributors partially and simultaneously. This research design using a type of causal research. The population of this study were all distributors registered at Tiens Authorized Store 618 are 4.169 people. The sample of this study amounted to 371 respondents using the proportional random sampling method. The data collection technique was carried out by distributing questionnaires with a Likert scale and processed using multiple linear regression analysis technique. The result of data analysis showed that there was a partially positive and significant effect on the achievemnt motive towards achieving the sale target of Tiens Bali distributors, shown from the value of $t=13.491$ with a Sig. of 0.000. Self efficacy, partially has a positive and significant effect on achieving the sales target of Tiens Bali distributors, shown from the value of $t=12.915$ with a Sig. of 0.000. Achievement motives and self efficacy have a simultaneous positive effect on achieving sales targets of Tiens Bali distributors, shown by the value of $F=323.925$ and a Sig. of 0.000 .
\end{abstract}

Keywords : achievement motives; self efficacy; sales targets 


\section{PENDAHULUAN}

Kemajuan ekonomi suatu bangsa, salah satunya ditentukan oleh tingkat kewirausahaan di dalam bangsa itu. Jumlah entrepreneur di negara maju ada pada rerata angka $14 \%$ penduduk. Angka tersebut lebih tinggi dibandingkan dengan jumlah entrepreneur di Indonesia yang masih 3,1\% (Kompas.com, 5/4/2018) Artinya, apabila ingin Indonesia maju diperlukan percepatan pengembangan kewirausahaan. Rendahnya jumlah entrepreneur ini, mengakibatkan lapangan pekerjaan dalam dunia usaha menjadi sempit, tidak sebanding dengan meningkatnya jumlah masyarakat yang membutuhkan pekerjaan. Sebagian besar dari para lulusan dari lembaga pendidikan tidak dapat ditampung dikarenakan persaingan dengan orang-orang yang lebih berpengalaman dalam mencari kerja, sehingga para lulusan dari lembaga pendidikan setiap tahunnya harus menghadapi kenyataan menjadi pengangguran.

Memiliki sebuah usaha merupakan salah satu alternatif terbaik untuk mengatasi pengangguran. Namun, untuk memulai usaha tidak semua orang mempunyai modal yang cukup besar, produk yang unik, dan keahlian mengelola bisnis serta keberanian menghadaoi resiko. Sehingga Network marketing (pemasaran jaringan) menjadi suatu usaha ataupun bisnis yang menjadi pilihan masyarakat. Sistem pemasaran ini sedang populer di Indonesia dengan konsep pemasaran berorientasi pada konsumen. Konsep pemasaran dengan sistem ini mengarahkan individu membangun oraganisasi bisnis pemasar sehingga membentuk jaringan kerja. Sistem dan cara kerja telah disiapkan oleh perusahaan untuk para membernya dalam mengenalkan serta menawarkan produk atapun jasa dari perusahaan.

Network marketing lebih mengutamakan pengembangan sumber daya manusia karena tidak terdapat syarat khusus bagi seorang yang minat menjalankan usaha dengan sistem ini. Sehingga perusahaan menyediakan support system untuk melatih para anggota yang tergabung menjadi seorang pemasar yang profesional dalam menjelaskan dan menawarkan produk atapun peluang usaha kepada orang lain. Penjualan bulanan sebagai syarat keaktifan dan sumber penghasilan para pemasar jaringan. Pembonusan diperhitungkan setiap bulan oleh perusahaan dalam bentuk bonus atau komisi dari hasil penjualan pribadi dan jaringan. Jumlah bonus atau komisi yang diberikan oleh perusahaan ditentukan oleh peringkat serta omset para distributor setiap bulan sebagai upaya mendorong kinerja individualnya.

Perusahaan yang memasarkan produk serta peluang bisnis menggunakan pendekatan network marketing salah satunya adalah Tiens Internasional. Seseorang yang menjalankan peluang bisnis dari Tiens disebut sebagai Distributor. Distributor Tiens mempunyai kinerja yang bervariasi, ditunjukkan dari penjualan serta jumlah merekrut member baru setiap bulan terdapat perbedaan keberhasilan dalam mencapai target antar Distributor. Keberhasilan seseorang mencapai target penjualan dalam menjalankan bisnis pemasaran jaringan ditentukan oleh kinerjanya sendiri.

Namun fenomena yang terjadi banyak distributor baru Tiens merasa diasingkan dari lingkungannya, malu dikatakan sebagai penjual suplemen makanan, dan merasa kurang mampu memasarkan produk dan menawarkan peluang bisnis Tiens kepada orang lain. Penolakan ketika menawarkan produk dan peluang bisnis Tiens membuat para distributor baru memiliki keyakinan bahwa dirinya tidak cocok dan tidak mampu dalam profesi ini. Kondisi ini dapat mengakibatkan turunnya pencapaian target, motivasi serta kinerja seorang jika tidak dikonsultasikan kepada tim kerja atau upline. Upline dalam bisnis Tiens adalah orang yang mengenalkan dan merekrut seseorang ke dalam bisnis ini. Mengatasi kondisi ini seorang Distributor harus memiliki alasan atau dorongan dalam diri serta mempunyai keyakinan bahwa mampu mengatasi kendala ketika menjalankan bisnis untuk mencapai target penjualan.

Target penjualan merupakan salah satu dari rencana pemasaran. Menurut Tenardhi (2012:128) "target penjualan 
merupakan tujuan penting yang hendak dicapai agar menghasilkan penjualan yang menguntungkan". Sebagai pedoman kerja, target penjualan mengindikasikan keinginan perusahaan untuk maju dan berkembang. Faktor-faktor yang dapat mempengaruhi pencapaian target penjualan seseorang menurut Tenardhi (2012) yaitu mindset positif ( pola pikir positif), winning attitude (sikap pemenang), ambisi, reward dan award (komisi penjualan dan penghargaan), pengalaman, dan sikap optimisme.

Dari faktor-faktor yang mempengaruhi pencapaian target penjualan menurut Tenardhi (2012) di atas maka faktor winning attitude (sikap pemenang), ambisi, reward dan award (komisi penjualan dan penghargaan), dan sikap optimis merupakan ciri-ciri dari orang yang mempunyai motif berprestasi tinggi, hal ini sesuai dengan yang dinyatakan oleh Suryana (2010). Menurut Suryana (2010) orang-orang yang memiliki motif berprestasi tinggi mempunyai dorongan dalam diri untuk membentuk mental yang unggul dalam mengerjakan segala sesuatu sehingga mampu berhasil melebihi standar sebuah pencapaian. Kemudian faktor Mindset positif (pola pikir positif) merupakan pola pikir yang dimiliki oleh seseorang yang mempunyai self efficacy tinggi dan pengalaman merupakan sumber untuk meningkatkan self efficacy seseorang menurut (Brown, dkk, 2013). Sehingga berdasarkan pemaparan di atas diduga motif berprestasi dan self efficacy dapat mempengaruhi pencapaian target penjualan.

Menurut Triningtyas (2016) mencapai tujuan yang telah dibuat diawal adalah alasan seorang pebisnis untuk menjalankan usaha. Tujuan akan bisa dicapai apabila mampu melaksanakan penjualan sesuai dengan perencanaan. Keahlian dalam mengelola usaha sangat menentukan dalam mencapai keberhasilan penjualan produk sehingga mendapatkan keuntungan. Apabila tidak mempunyai kemampuan mengelola dan menjual maka dipastikan akan mengalami kerugian.

Dalam mengelola aktivitas usaha menjual maka sesorang harus mampu menjual, bahkan seseorang harus selalu mempunyai target dalam melakukan penjualan. Mencapai target penjualan merupakan salah satu target dalam mengelola usaha penjualan sebagai bentuk motivasi dan perangsang bagi para penjual. Menurut Tenardhi (2012), indikator yang digunakan untuk mengukur target penjualan yang pertama kemampuan mencapai target bisnis, kedua adalah kemampuan menghasilkan bonus, ketiga yaitu kemampuan meningkatkan volume penjualan serta yang keempat adalah kemampuan menyeponsori Distributor baru.

Keyakinan pada diri (self efficacy) serta motif yang terdapat pada diri setiap orang merupakan faktor yang menentukan tingkat kinerja seseorang (Mangkuprawira dan Aida, 2007). Begitu juga dalam hal pencapaian sebuah target penjualan. Motif berprestasi memiliki arti sebagai dorongan dalam diri seseorang dalam mengupayakan kemampuannya untuk mencapai sukses (Sutrisno, 2015). Menurut Suharyadi, dkk (2007) motif berprestasi sebagai bentuk keinginan mencapai kepuasan pribadi yang menekankan pada nilai sosial. Sedangkan menurut Kasmir (2014) motif berprestasi adalah ukuran dari upaya yang dilakukan untuk mencapai keberhasilan dan kompetensi. Jadi, dorongan yang sumbernya dari diri seseorang untuk mengupayakan potensi diri dalam mencapai sebuah tujuan merupakan pengertian dari motif berprestasi.

Suryana (2010) menyatakan bahwa motif berprestasi sebagai dasar dari proses psikologi dan mampu mendeskripsikan suatu perilaku atau upaya seseorang. Orang-orang dengan motif berprestasi tinggi umumnya berkomitmen dan bertanggung jawab terhadap pekerjaan yang ditugaskan kepadanya. Biasanya mampu melihat serta mengolah peluang yang ada dan cenderung menyukai tantangan. Selain itu orang yang mempunyai motif berprestasi tinggi ketika mengeluarkan kritik ataupun saran yang objektif, menyukai penghargaan (reward), optimis walaupun dalam keadaan yang buruk sekalipun, serta orientasi pada keuntungan dan proaktif dalam mengelola suatu hal. Hal serupa disampaikan oleh Tenardhi (2012) bahwa seseorang dengan motif berprestasi tinggi memiliki sikap sebagai seorang pemenang, ambisi besar, tertantang untuk meraih reward dan award (komisi penjualan dan penghargaan) dan 
sikap yang optimis. Motif berprestasi yang dimiliki seseorang akan mampu mendorong penjualan lebih meningkat lagi. Indikator yang digunakan untuk mengukur variabel motif berprestasi adalah pekerja keras, tidak pernah menyerah, memiliki semangat, serta memiliki komitmen. Dengan adanya motif berprestasi yang kuat dari seseorang tentunya dapat menjadi sebuah dorongan untuk pencapaian target penjualan.

Konsep self efficacy diperkenalkan oleh Albert Bandura yang memiliki pengertian tentang otoritas diri, kepercayaan untuk mencapai target yang telah ditetapkan (Yusuf, 2019). Self efficacy adalah kepercayaan orang pada dirinya sendiri terhadap kesanggupan dalam mengatasi situasi, mengatur dan menguasai suatu keadaan dan pada akhirnya mencapai keberhasilan (Maryam, 2015). Self efficacy diartikan keyakinan individu terhadap kemampuannya sendiri dalam berusaha mengatasi setiap tantangan dan kesulitan untuk mencapai sesuatu (Brown, dkk, 2013). Disimpulkan bahwa self efficacy sebagai kepercayaan diri seseorang pada keahliannya melakukan upaya untuk mengatasi tantangan untuk mencapai keberhasilan.

Secara mendalam fungsi self afficacy yang pertama adalah seseorang mampu menentukan sikap dan tingkah laku mengenai yang sesuatu yang dihadapinya. Orang dengan keyakinan diri yang tinggi cenderung mempunyai fokus yang kuat dengan kemampuan diri terhadap suatu hal yang yakin bisa ia selesaikan. Dalam hal ini self efficacy dapat menimbulkan tingkah laku seseorang.

Fungsi yang kedua adalah dapat menentukan besar upaya dan keyakinan seseorang ketika menghadapi tantangan dan proses yang yang dihadapi. Dengan self efficacy yang tinggi seseorang akan lebih kuat dan selalu berupaya mencari solusi hingga apa yang yang direncanakan tercapai.

Fungsi ketiga dari self efficacy adalah mempunyai pandangan dan reaksi emosional dalam menyelesaikan persoalan yang dihadapi. Self efficacy yang tinggi pada diri seseorang akan mampu bereaksi yang positif terhadap suatu masalah sehingga mampu menemukan solusi dan memposisikan bahwa masalah adalah suatu hal yang wajar dihadapi untuk proses meningkatkan kemampuan diri. Namun sebaliknya dengan orang yang memiliki self efficacy yang rendah biasanya melihat suatu masalah sebagai beban yang sangat berat dan ragu mampu ia selesaikan serta cenderung memiliki pandangan bahwa akan munculn masalah baru yang lebih berat lagi kedepannya.

Kemudian fungsi yang keempat adalah sebagai penentu tingkah laku berikutnya. Orang dengan self efficacy tinggi kecenderungan yakin terhadap dirinya dan mempunyai ketertarikan dan keaktifan yang tinggi dengan lingkungannya. Selalu berusaha dengan keras untuk mengatasi setiap masalah yang dihadapi tanpa mudah menyerah dan putus harapan. Sebaliknya kurang self efficacy terdapat kecenderungan mudah malu dan kurang aktif terlibat dalam suatu kegiatan atau pekerjaan yang dihadapi untuk mengupayakan memperbaiki kondisi menjadi lebih baik

Ketika dihadapkan dengan masalah yang sulit, individu dengan self efficacy tinggi merasa mampu untuk menyelesaikan persoalan dan menyimpulkan bahwa dirinya tidak berhasil diakibatkan kurang daya upaya lalu akan mengambil tindakan seperti semakin komitmen dan konsisten dalam mencapai hasil maksimal, sedangkan kurangnnya self efficacy dalam diri seseorang akan terjadi kecenderungan terhadap sudut pandang bahwa ketidakberhasilan dalam mencapai tujuan berasal dari ketidaksanggupan dirinya. Keraguan akan muncul pada dirinya yang kemudian akan menurunkan daya upaya bahkan akan berhenti berusaha.

Menurut Tenardhi (2012) self efficacy merupakan keyakinan yang muncul dari diri seseorang terhadap kemampuannya untuk menghadapi sebuah tantangan untuk mencapai target. Seseorang dengan self efficacy tinggi memiliki pola pikir positif sehingga mampu memaksimal kemampuan diri, dapat berpikir secara luas, dan fokus dalam melaksanakan sebuah kegiatan. Dengan self efficacy tinggi yang dimiliki seseorang menjadikan seseorang mempunyai keyakinan kuat untuk mencapai sesuatu serta tidak mudah menyerah. Indikator untuk mengukur variabel self 
efficacy dalam penelitian ini adalah keyakinan dapat menyelesaikan tugas tertentu, kedua yaitu keyakinan dapat memotivasi diri, ketiga adalah berusaha dengan keras, gigih dan tekun, kemudian yang keempat bertahan menghadapi hambatan dan kesulitan serta kelima adalah mampu menyelesaikan permasalahan di berbagai situasi. Tingginya tingkat self efficacy yang dimiliki para Distributor akan mampu membantu mengembalikan semangat dalam mengupayakan seluruh potensi yang dimiliki setelah penolakan yang didapatkan ketika menjalani proses pemasaran produk untuk mencapai kesuksesan dalam mencapai target. Seseorang harus memiliki kepercayaan diri untuk mampu mengelola usahanya sehingga mampu mencapai target dalam usahanya.

\section{METODE}

Dari pemaparan diatas maka penelitian tentang pengaruh motif berprestasi dan self efficacy terhadap pencapaian target penjualan para distributor Tiens Bali dipandang perlu untuk diadakan. Penelitian ini dilakukan agar para pelaku bisnis Tiens dapat menumbuhkan dorongan serta keyakinan dalam diri untuk memulai atau menjalankan sebuah bisnis, sehingga mampu menyikapi peluang, menetapkan strategi dan mengembangkan bisnis dalam bidang penjualan langsung.

Penelitian ini dilaksanakan di Tiens Authorized Store 618 yang memiliki 6 cabang di Bali. Seluruh distributor yang terdaftar di Tiens Authorized Store 618 pada tahun 2017 sampai 2018 sebagai populasi yang ditetapkan dalam penelitian dengan jumlah keseluruhan sebanyak 4.169 orang

Perhitungan jumlah sampel yang mewakili populasi penelitian menggunakan rumus Slovin (Umar, 2005) sebagai berikut.

$\mathrm{n}=\frac{\mathrm{N}}{1+\mathrm{N} \cdot \mathrm{e}^{2}}$

$\mathrm{n}=371,40$ dibulatkan menjadi 371

Dari perhitungan di atas, maka didapatkan sampel 371 orang. Kemudian dari 371 sampel dilanjutkan dengan penentuan jumlah yang seimbang dari setiap wilayah dikarenakan Tiens
Authorized Store 618 di Bali memiliki enam cabang. Penentuan jumlah sampel secara proporsional pada setiap wilayah dapat menggunakan teknik pengambilan sampel proportional random sampling (Arikunto, 2006). Membagi sampel untuk setiap Kabupaten digunakan rumus menurut (Sugiyono (2012).

$n=\frac{X}{N} x N 1$

Dimana:

$\mathrm{n} \quad$ : banyaknya sampel disetiap strata

$\mathrm{N}$ : Ukuran populasi

$X$ : Ukuran populasi pada setiap strata

N1 :Sampel

Perhitungan sampel untuk tiap-tiap Kabupaten tampak di tabel 1.

Tabel 1. Distribusi Sampel Penelitian

\begin{tabular}{ccc}
$\begin{array}{c}\text { Kabupaten/ } \\
\text { Kota }\end{array}$ & $\begin{array}{c}\text { Jumlah } \\
\text { Popula } \\
\text { si }\end{array}$ & $\begin{array}{c}\text { Jumlah } \\
\text { Sampel }\end{array}$ \\
\hline Denpasar & 1.099 & $\frac{1.099}{4.169} \times 371=98$ \\
Buleleng & 1.057 & $\frac{1.057}{4.169} \times 371=94$ \\
Gianyar & 694 & $\frac{694}{4.169} \times 371=62$ \\
$\begin{array}{c}\text { Karangase } \\
\text { m }\end{array}$ & 581 & $\frac{581}{4.169} \times 371=52$ \\
Badung & 524 & $\frac{524}{4.169} \times 371=46$ \\
Bangli & 214 & $\frac{214}{4.169} \times 371=19$ \\
\hline Jumlah & 4.169 & 371 \\
\hline
\end{tabular}

Dari perhitungan menggunakan rumus diatas, sampel distributor Tiens di Kota Denpasar sebesar 98 orang, Kabupaten Buleleng berjumlah 94 orang, Kabupaten Gianyar sebanyak 62 orang, sejumlah 52 orang di Kabupaten Karangasem, 46 orang di Kabupaten Badung dan Kabupaten Bangli sebesar 19 orang.

Rancangan penelitian ini menggunakan rancangan kausal dengan jenis data kuantitatif. Data yang yang akan dianalisis bersumber dari data primer yaitu jawaban responden secara langsung melalui kuesioner yang disebar kepada 371 
distributor Tiens mengenai motif berprestasi, self efficacy, dan target penjualan. Selain itu data yang dibutuhkan adalah data sekunder yaitu data mengenai jumlah Distributor yang terdaftar di Tiens Authorized Store 618 pada tahun 2017 sampai 2018. Skala likert digunakan dalam penelitian ini untuk menentukan skor dari setiap pernyataan dalam kuesioner. Menurut Sugiyono (2012) apabila akan meneliti fenomena sosial terkait dengan sikap, pendapat dari individu ataupun kelompok maka dapat menggunakan skala ukur likert. Terdapat lima jawaban pada setiap pernyataan dengan skor 5 sampai 1 dengan kategori sangat setuju sampai sangat tidak setuju.

Instrumen untuk mengumpulkan data harus di uji kualitas data dan keabsahannya terlebih dahulu. Pengujian instrument dilakukan dengan uji validitas dan reabilitas. Instrumen dapat dinyatakan valid ditentukan dengan nilai r-hitung harus lebih besar daripada r-tabel dengan taraf signifikan adalah 5\%. Kemudian untuk mengetahui kuesioner reliable maka harus dilihat pada nilai cronbach alpha $>0,60$.

Setelah data dikumpulkan dengan penyebaran kuesioner lalu melangkah ke penganalisisan dengan analisis regresi linier berganda. Tahapan analisisnya yaitu pengujian statistik $t$ yaitu menguji secara parsial pengaruh antara motif berprestasi terhadap pencapaian target penjualan dan self efficacy terhadap pencapaian target penjualan. Pengujian statistik $F$ juga dilakukan untuk menguji secara simultan yaitu untuk dapat mengetahui pengaruh variabel bebas (motif berprestasi dan self efficacy) secara bersamaan terhadap variabel terikat (target penjualan).

Kemudian dilanjutkan dengan analisis regresi linier berganda. Menurut Ghozali (2018) menjelaskan mengenai analisis regresi linier berganda sebagai salah satu analisis untuk meneliti pengaruh dua atau lebih variabel independent terhadap variabel dependent. Pengujian ini melihat pengaruh motif berprestasi $\left(X_{1}\right)$ dan self efficacy $\left(X_{2}\right)$ terhadap target penjualan $(Y)$. Model regresi yang digunakan dapat dirumuskan (Ghozali, 2018) adalah sebagai berikut.

$$
\hat{Y}=\alpha+\beta_{1} X_{1}+\beta_{2} X_{2}+e
$$

Dimana:

$\hat{Y}$ : Variabel terikat (Target penjualan)

$\alpha$ : Konstanta dari persamaan regresi

$\beta_{1} \beta_{2} \quad$ : Koefisien arah regresi

$\mathrm{X}_{1}$ : Variabel bebas (Motif

berprestasi)

efficacy)

$\mathrm{X}_{2}$ : Variabel terikat (Self

\section{e : Tingkat kesalahan atau gangguan}

Pengujian kelayakan model regresi dengan uji asumsi klasik juga dilakukan seperti uji normalitas, multikolonearitas, dan heteroskedastisitas (Ghozali, 2018). Pengujian asumsi klasik normalitas bertujuan untuk memastikan variabel bebas dan variabel terikat berdiistribusi normal. Pengujian menggunakan analisis grafik dan uji statistik (Ghozali, 2018). One Sample Kolmogorov-Smirnov test digunakan untuk menguji normalitas residual dengan tingkat signifikan 5\%. Data terdistribusi normal apabila nilai Sig lebih dari atau sama dengan 0,05 .

Pengujian asumsi klasik yang kedua adalah multikolinieritas untuk memastikan antara variabel bebas tidak memiliki hubungan satu sama lain. Pendeteksian multikolinieritas dengan melihat matriks korelasi antara variabel bebas dan hasil perhitungan dari nilai Tolerance dan VIF (Variance Inflation Factor). Dasar pengujian untuk memastikan tidak terjadi multikolinieritas apabila nilai Tolerance lebih kecil atau sama dengan 0,10 dan nilai VIF berada di atas atau sama dengan 10 (Ghozali, 2018).

Pengujian

asumsi klasik heteroskedastisitas untuk memastikan di di dalam suatu model regresi terdapat ketidaksamaan varian dari residual satu variabel ke variabel lain. Dasar pengujian heteroskedastisitas dengan uji Glejser untuk memastikan tidak terjadi heteroskedastisitas maka terlihat pada nilai probabilitas sig. harus melebihi standar 5\% (Ghozali, 2018). Program IBM SPSS versi 16.0 for Windows digunakan untuk seluruh pengujian data di penelitian ini.

Kriteria pengujian hipotesis secara simultan, ketika tingkat signifikansi $<0,05$ artinya menolak Ho, disimpulakan terdapat pengaruh signifikan dan positif secara simultan, sedangkan ketika tingkat 
signifikansi > 0,05 artinya menerima Ho, disimpulkan secara simultan tidak berpengaruh signifikan dan positif. Kemudian untuk mentukan berpengaruh secara parsial, ketika tingkat signifikansi < 0,05 berarti menolak Ho yang artinya setiap variabel bebas berpengaruh terhadap variabel terikat, sedangkan ketika nilai signifikansi $>0,05$ berarti menerima Ho mengartikan bahwa setiap variabel bebas tidak memiliki pengaruh secara parsial terhadap variabel terikat.

\section{HASIL DAN PEMBAHASAN}

Hasil

Berdasarkan tahapan pengujian statistik $t$ yang dilakukan menunjukkan bahwa pengaruh motif berprestasi terhadap pencapaian target penjualan para Distributor Tiens Bali memiliki hubungan yang positif dan signifikan. Hasil Pengujian statistik $t$ untuk variabel motif berprestasi terrhadap pencapaian target penjualan ditunjukan di table 2.

Tabel 2. Hasil Uji t untuk Pengaruh Variabel Motif Berprestasi terhadap Pencapaian Target Penjualan

\begin{tabular}{|c|c|c|c|c|c|c|}
\hline \multirow{2}{*}{\multicolumn{2}{|c|}{ Model }} & \multicolumn{2}{|c|}{ Unstandardized Coefficients } & \multirow{2}{*}{$\begin{array}{c}\text { Standardized } \\
\text { Coefficients } \\
\text { Beta }\end{array}$} & \multirow[t]{2}{*}{$t$} & \multirow[t]{2}{*}{ Sig. } \\
\hline & & $B$ & Std. Error & & & \\
\hline \multirow[t]{2}{*}{1} & (Constant) & 5.016 & 0,892 & & 5,621 & 0,000 \\
\hline & Motif berprestasi & 0,371 & 0,028 & 0,477 & 13,491 & 0,000 \\
\hline
\end{tabular}

a. Dependent Variable: Target penjualan

Tabel 2 menunjukkan variabel motif berprestasi memiliki nilai $t$ sebesar 13,491 . Nilai signifikan sebesar 0,000 yang menunjukkan bahwa nilai signifikan motif berprestasi lebih kecil dari 0,05. Hal ini berarti ada pengaruh motif berprestasi terhadap pencapaian target penjualan para Distributor Tiens Bali. Maka Ho ditolak. Pengaruh self efficacy terhadap pencapaian target penjualan para Distributor Tiens Bali dapat diketahui dengan pengujian statistik $\mathrm{t}$ pada tabel 3.

Tabel 3. Hasil Uji t untuk Pengaruh Variabel Self Efficacy terhadap Pencapaian Target Penjualan

\begin{tabular}{|c|c|c|c|c|c|c|}
\hline & \multirow[t]{2}{*}{ Model } & \multicolumn{2}{|c|}{ Unstandardized Coefficients } & \multirow{2}{*}{$\begin{array}{c}\text { Standardized } \\
\text { Coefficients } \\
\text { Beta }\end{array}$} & \multirow[t]{2}{*}{$t$} & \multirow[t]{2}{*}{ Sig. } \\
\hline & & $\mathrm{B}$ & Std. Error & & & \\
\hline \multirow[t]{2}{*}{1} & (Constant) & 5.016 & 0,892 & & 5,621 & 0,000 \\
\hline & Self efficacy & 0,300 & 0,023 & 0,457 & 12,915 & 0,000 \\
\hline
\end{tabular}

a. Dependent Variable: Target penjualan

Nilai $t$ self efficacy pada tabel 3 sebesar 12,915. Nilai signifikan sebesar 0,000 menjelaskan bahwa tingkat signifikan self efficacy kurang dari 0,05. Berarti ada pengaruh self efficacy terhadap pencapaian target penjualan para Distributor Tiens Bali.
Sehingga Ho ditolak. Pengaruh motif berprestasi dan self efficacy terhadap pencapaian target penjualan para Distributor Tiens Bali secara simultan diujikan dengan uji $\mathrm{F}$.

Hasil analisa terdapat di tabel 4.

Tabel 4. Hasil Uji F untuk Pengaruh Variabel Motif Berprestasi dan Self Efficacy terhadap Pencapaian Target Penjualan

\begin{tabular}{|c|c|c|c|c|c|c|}
\hline & Model & Sum of Squares & $D f$ & Mean Square & $\mathrm{F}$ & Sig. \\
\hline \multirow[t]{3}{*}{1} & Regression & 4851,302 & 2 & 2425,651 & 323,925 & 0,000 \\
\hline & Residual & 2755,697 & 368 & 7,488 & & \\
\hline & Total & 7606,999 & 370 & & & \\
\hline
\end{tabular}


Hasil tersebut mengartikan terdapat pengaruh motif berprestasi dan self efficacy terhadap pencapaian target penjualan para Distributor Tiens Bali. Maka Ho ditolak. Besar pengaruh motif berprestasi dan self efficacy terhadap pencapaian target penjualan dapat diketahui melalui persamaan regresi pada koefisien beta sebagai berikut.

Tabel 5. Hasil Perhitungan Koefisien Beta

\begin{tabular}{llccccc}
\hline \multirow{2}{*}{ Model } & \multicolumn{2}{c}{$\begin{array}{c}\text { Unstandardized } \\
\text { Coefficients }\end{array}$} & $\begin{array}{c}\text { Standardized } \\
\text { Coefficients } \\
\text { Beta }\end{array}$ & $\mathrm{t}$ & Sig. \\
& $\mathrm{B}$ & Std. Error & Beta & & \\
\hline 1 & (Constant) & 5,016 & 0,892 & & 5,621 & 0,000 \\
& Motif berprestasi & 0,371 & 0,028 & 0,477 & 13,491 & 0,000 \\
& Self efficacy & 0,300 & 0,023 & 0,457 & 12,915 & 0,000 \\
\hline
\end{tabular}

a. Dependent Variable: Target penjualan

Hasil yang tertera pada tabel 5, dapat dirumuskan persamaan atau model regresi di bawah ini.

$\hat{Y}=5,016+0,371 X_{1}+0,300 X_{2}$

Keterangan:

$\hat{Y}=$ target penjualan

$\mathrm{X}_{1}=$ motif berprestasi

$\mathrm{X}_{2}=$ self efficacy

Dari model persamaan regresi yang dibuat, mampu menjelaskan bahwa konstanta sebesar 5,016 menunjukkan apabila variabel motif berprestasi $\left(X_{1}\right)$ dan self efficacy $\left(X_{2}\right)$ bernilai tetap atau nol, maka variabel target penjualan (Y) mempunyai Nilai positif sebesar 5,016. Koefisien variabel motif berprestasi $\left(X_{1}\right)$ dan self efficacy bernilai positif yaitu sebesar 0,371 dan 0,300 . Koefisien regresi bernilai positif menunjukkan bahwa motif berprestasi $\left(\mathrm{X}_{1}\right)$ dan self efficacy $\left(\mathrm{X}_{2}\right)$ terdapat pengaruh positif terhadap target penjualan (Y). Sehingga dapat menggambarkan bahwa peningkatan motif berprestasi $\left(\mathrm{X}_{1}\right)$ dan self efficacy $\left(\mathrm{X}_{2}\right)$ sebanyak satu satuan maka akan diikuti peningkatan pada pencapaian target penjualan (Y) sebanyak nilai koefisien beta di setiap variabel bebasnya. Contohnya, jika motif berprestasi $\left(X_{1}\right)$ naik sebesar satu satuan, maka dapat meningkatkan pencapaian target penjualan $(Y)$ sebesar 0,371 dan setiap self efficacy $\left(X_{2}\right)$ meningkat sebesar satu satuan, maka terjadi peningkatan pada pencapaian target penjualan (Y) sebesar 0,300 . Sehingga dapat di interprestasikan bahwa semakin tingginya motif berprestasi dan self efficacy akan menyebabkan meningkatnya pencapaian target penjualan. Kemudian semakin rendah motif berprestasi dan self efficacy, maka pencapaian target penjualan akan semakin rendah.

\section{Pembahasan}

Hasil analisis data menunjukkan terdapat pengaruh siginifikan antara motif berprestasi terhadap pencapaian target penjualan. Pengaruh positif menunjukkan bahwa hubungan motif berprestasi dan pencapaian target penjualan itu searah. Apabila motif berprestasi semakin baik, maka pencapaian target penjualan semakin tinggi pula. Hasil ini didukung oleh pendapat Wijaya dkk. (2015) bahwa motif berprestasi yang dimiliki seseorang dapat menumbuhkan dorongan mengeluarkan tingkah laku atau perbuatan yang positif serta bermanfaat untuk mencapai tujuan atau sasaran (target) yang diinginkan. Kotler (2016) mengemukakan bahwa jika seorang penjual memiliki motivasi tinggi cenderung mempunyai upaya tinggi sehingga akan mampu menghasilkan pencapaian target yang tinggi pula. Sehingga pelaku usaha (distributor Tiens) harus memiliki motif berprestasi untuk mencapai target penjualan. Sebagai distributor baru dengan keterbatasan keahlian dalam menjalankan bisnis Tiens yaitu sebagai pemasaran jaringan ketika mengalami kesulitan seperti penolakan maka motif berprestasi berperan dalam diri seseorang sebagai pendorongan dan alasan untuk mencapai sukses. Distributor dengan tingkat motif berprestasi yang tinggi 
percaya bahwa kerja keras, pantang menyerah, semangat dan komitmen yang telah dikeluarkan pasti akan mampu mencapai target bisnis dan mengembangkan bisnisnya untuk menghasilkan pencapaian target penjualan yang lebih besar serta merekrut orang baru. Sehingga mereka yakin bahwa akan memperoleh imbalan berupa bonus dan penghargaan dari perusahaan sesuai dengan hasil kerja dan harapan mereka. Hal ini didukung oleh Intan (2017) dalam penelitiannya menyatakan hasil bahwa variabel motivasi beprestasi terhadap variabel kinerja dari agen pemasaran asuransi memiliki hubungan positif dan siginifikan. Hasil penelitian yang ditemui oleh Hidayat (2010) bahwa motivasi kerja berkontribusi secara tepat terhadap penjualan.

Self efficacy terhadap pencapaian target penjualan berpengaruh siginifikan Pengaruh positif menjelaskan bahwa keterkaitan yang searah antara self efficacy terhadap target penjualan. Jika self efficacy semakin tinggi, maka pencapaian target penjualan semakin tinggi. Hasil Penelitian dari Permatasari (2015) mendukung penelitian ini, bahwa self efficacy merupakan keyakinan karyawan bahwa dirinya memiliki keterampilan dan mampu mencapai target penjualan dengan sukses, jika self efficacy tinggi maka harapan karyawan untuk menghasilkan tingkat kinerja tertentu akan tinggi. Prasetyo (2019) mengungkapkan bahwa keyakinan akan efikasi diri merupakan faktor kunci human agency. Tingginya efikasi diri dapat mendorong distributor untuk mencapai target penjualan yang diinginkan. Mencapai sebuah target penjualan merupakan tugas seorang distributor yang memutuskan untuk serius dalam menjalankan usahanya. Jadi, distributor Tiens yang memiliki self efficacy yang baik akan mampu mengeluarkan segala potensi yang ada dalam dirinya untuk berusaha sehingga dapat mencapai target penjualan setiap bulannya. Distributor yang memiliki keyakinan tinggi terhadap tugas yang dapat diselesaikan, mampu memotivasi diri, berusaha dengan keras, gigih dan tekun, bertahan menghadapi hambatan dan kesulitan, serta keyakinan diri bahwa mampu menyelesaikan setiap permasalahan akan membuat distributor bertahan dalam menjalani setiap tantangan ataupun penolakan ketika memasarkan produk ataupun peluang usaha dan berjuang sampai mampu mencapai target bisnis, bonus, serta meningkatkan penjualan dan mengembangkan jaringan bisnis. Hasil penelitian terdahulu dari Zainuddin (2016), menemukan bahwa self efficacy dan kinerja distributor berpengaruh siginifikan. Intan (2017) menemukan adanya pengaruh self efficacy dengan kinerja dari agen pemasaran asuransi dengan hasil yang signifikan. Jadi, dari penjelasan hasil penelitian variabel self efficacy terhadap pencapaian target penjualan disimpulkan bahwa terdapat pengaruh signifikan.

Motif berprestasi dan self efficacy terhadap pencapaian target penjualan secara simultan bepengaruh signifikan. Jika motif berprestasi dan self efficacy semakin baik, maka pencapaian target penjualan semakin tinggi. Syahyono (2016) mengemukakan pernyataan yang mendukung penelitian ini, bahwa motivasi mempunyai arti penting pada setiap organisasi dalam upaya meningkatkan hasil penjualan sebagai bentuk keproduktifan. Permatasari (2015) mengungkapkan bahwa self efficacy merupakan keyakinan karyawan bahwa dirinya memiliki keterampilan dan mampu mencapai target penjualan dengan sukses, jika self efficacy tinggi maka harapan karyawan untuk menghasilkan tingkat kinerja tertentu akan tinggi. Motif berprestasi dan self efficacy adalah suatu hal penting yang harus ada pada diri distributor untuk mencapai target penjualan. Memiliki dorongan dalam diri yang tinggi dan kepercayaan diri terhadap kemampuannya menyelesaikan berbagai tantangan dapat meningkatkan semangat dan antusias para distributor untuk dapat mencapai target penjualan. Penelitian yang telah dilakukan oleh Intan (2017), menemukan bahwa variabel self efficacy dan motivasi beprestasi memiliki pengaruh yang siginifikan terhadap variabel kinerja agen pemasaran asuransi.

\section{SIMPULAN DAN SARAN}

Simpulan 
Berdasarkan pengujian hasil data dan pembahasan hipotesis dari pengaruh motif berprestasi dan self efficacy terhadap pencapaian target penjualan para distributor Tiens Bali, maka disimpulan sebagai berikut. Pertama, terdapat pengaruh motif berprestasi terhadap pencapaian target penjualan para distributor Tiens Bali, yang ditunjukkan dari nilai $t=13,491$ dengan nilai Sig. sebesar 0,000 lebih kecil dari 0,05. Kedua, ada pengaruh self efficacy terhadap pencapaian target penjualan para distributor Tiens Bali, yang ditunjukkan dari nilai $\mathrm{t}=$ 12,915 dengan nilai Sig. sebesar 0,000 lebih kecil 0,05. Ketiga, ada pengaruh motif berprestasi dan self efficacy terhadap pencapaian target penjualan para distributor Tiens Bali, yang ditunjukkan dengan nilai $F$ $=323,925$ dengan nilai Sig. sebesar 0,000 lebih kecil dari 0,05.

\section{Saran}

Berdasarkan pengujian hasil data, pembahasan, dan simpulan, maka peneliti memberikan saran yang diajukan sebagai berikut. Pertama, bagi distributor Tiens hendaknya dalam mengerjakan bisnis Tiens yakin bahwa target yang direncanakan diawal bulan dapat tercapai, strategi yang dikerjakan berjalan sesuai dengan target, reward dari perusahaan Tiens akan diterima, tidak menyerah ketika ada penolakan dari calon pembeli ketika menawarkan produk Tiens, setiap bulannya menghadiri pertemuan resmi Tiens untuk mendapatkan strategi meningkatkan penjualan, dan berbesar hati dalam mengahadapi penolakan dari calon pembeli ketika menawarkan produk Tiens. Hal ini dilakukan agar dapat memperkuat self efficacy, sehingga dapat meningkatkan pencapaian target penjualan. Kedua, bagi Peneliti berikutnya yang tertarik untuk meneliti aspek yang serupa mengenai pengaruh motif berprestasi dan self efficacy terhadap pencapaian target penjualan diharapkan untuk memperluas penelitian ini memperluas populasi serta sampel jadi tidak hanya di Distributor Tiens di Bali, tetapi juga di Distributor Tiens lainnya agar lebih teruji keandalannya.

\section{DAFTAR PUSTAKA}

Arikunto, S. (2006). Prosedur Penelitian Suatu Pendekatan Praktik. Jakarta: PT Reneka Cipta.

Brown, J. . (2013). Self-Efficacy Theory, 1338.

Ghozali, I. (2018). Aplikasi Analisis Multivariate dengan Program IBM SPSS 25 (9th ed.). Semarang: Badan Penerbit Undip.

Hidayat, C. (2010). Kontribusi Motivasi Kerja dan Penjualan Sales Person. Binus Business Review, 1(1), 222232.

Intan, G. A. (2017). Pengaruh Self Efficacy dan Motif Berprestasi Terhadap Kinerja Agen Pemasaran Asuransi Equity Life Indonesia Cabang Renon Denpasar. E-Jurnal Ekonomi Dan Bisnis Universitas Udayana, 4, 1547-1574.

Kasmir. (2014). Kewirausahaan. Jakarta: PT Rajagrafindo Persada.

Kotler, P. dan K. L. K. (2016). Marketing Management. New Jersey: Pearson Pretice Hall, Inc.

Kuwado, F. J. (2018). Jumlah Entrepreneur di Indonesia Jauh di Bawah Negara Maju, Ini Kata Jokowi.

Mangkuprawira, S. dan A. V. H. (2007). Manajemen Mutu Sumber Daya Manusia. Bogor: Ghalia.

Maryam, S. (2015). Self Efficacy Anak Didik Pemasyarakatan di LAPAS Anak Kelas IIA Blitar. Universitas Islam Malang.

Permatasari, A. A. (2015). Hubungan Antara Motivasi Kerja dan Kinerja Pada Karyawan Marketing di Distributor Ban " $X$ " Bandung. Universitas Kristen Maranatha.

Prasetyo, F. B. S. (2019). Hubungan antara Gairah Fisiologi dengan Efikasi Diri pada Sales Counter Ilufa Distribusindo. Universitas Sanata Dharma.

Sugiyono. (2012). Metode Penelitian Kuantitatif,Kualitatif dan R\&D. Bandung: PT Remaja Rosdakarya.

Suharyadi, D. (2007). Kewirausahaan: Membangun Usaha Sukses Sejak Usia Muda. Jakarta: Salemba Empat.

Suryana, Y. \& B. K. (2010). Kewirausahaan: Pendekatan Karakteristik Wirausaha Sukses. Jakarta: Kencana.

Sutrisno, E. (2015). Manajemen Sumber Daya Manusia. Jakarta: Kencana.

Syahyono. (2016). Pengaruh Motivasi Divisi 
Karyawan Marketing terhadap Tingkat Penjualan. Jurnal AKP, 6(1), 1-17.

Tenardhi, B. T. (2012). The 8 Continuums of Sales Management Process. Jakarta: Raih Asa Sukses.

Triningtyas, D. A. (2016). Dasar-Dasar Kewirausahaan. Jawa Timur: CV AE Media Grafika.

Umar, H. (2005). Riset Sumber Daya Manusia Dalam Organisasi. Jakarta: PT.Gramedia Pustaka Utama.

Wijaya, Agus, D. (2015). Kepemimpinan Berkarakter. Sidoarjo: Brilian Internasional.

Yusuf, R. I. (2019). Efikasi Diri dalam Akademik dan Kepemimpinan Mahasiswa: Sebuah Penelitian Empiris. (Rusmana, Ed.), The Future of Organizational Communication In The Industrial Era $4.0 \quad$ ((Eds)). Bandung: Media Akselerasi.

Zainuddin. (2016). Pengaruh Kepuasan Kerja, Motivasi, Komunikasi Interpersonal, Self Esteem, dan Self Efficacy Terhadap Kinerja Individual (Studi Empiris Pada Distributor Tiens Unicore di Makasar). El Muhasaba: Jurnal Akuntansi, 6(2), 1-19. https://doi.org/10.18860/em.v6i2.3905 